\title{
EFFECTS OF L-CARNITINE ON MORPHOLOGY AND ANTIOXIDANT ENZYMES AND DNA INTEGRITY OF CRYOPRESERVED BUFFALO SPERMATOZOA
}

\author{
BADR, M.A. ${ }^{1}$; EBTIHAL, A. IBRAHIM ${ }^{2}$; DOHREIG, R.M.A. ${ }^{1}$ HUSSEIN, M.S. ${ }^{3}$ and \\ HASSAN, H.M. ${ }^{4}$ \\ ${ }^{1}$ Artificial Insemination and Embryo Transfer Department, Animal Reproduction Research Institute, Al Haram (P.O.B. \\ 12556), Giza, Egypt. \\ ${ }^{2}$ Biology of Reproduction Department, Animal Reproduction Research Institute, Al Haram (P.O.B. 12556), Giza, Egypt. \\ ${ }^{3}$ Theriogenology Department, Veterinary Teaching Hospital, Fac. of Vet. Med. Mansoura University (P.O.B. 35516), Egypt. \\ ${ }^{4}$ Unit of Immunobiology and Immunopharmacology, Animal Reproduction Research Institute, Al Haram, (P.O.B. 12556), \\ Giza, Egypt.
}

Received: 31 December 2016; $\quad$ Accepted: 31 January 2017

\begin{abstract}
Cryopreservation induces sub lethal damage to the spermatozoa, thereby reduce their fertile life. There are some biochemical additives that may enhance buffalo semen freezability; L-carnitine is one of these biochemical semen additives. Till now, the exact effects of L-carnitine on buffalo semen processing outcomes haven't been discovered. The current study aimed to clarify L-carnitine roles during buffalo semen cryopreservation. Semen was cryopreserved in tris-based extender supplemented with different concentrations of L- carnitine $(0.01,0.05$ and $0.1 \mathrm{mg} / \mathrm{ml}$ ) Vs. Tris-based extender only (control). Then they were processed to cryopreservation and thawing to assess different semen characteristics. Cryopreserved semen was assessed for percentage post- thawing motility, acrosomal and plasma membrane integrity, viability, DNA damage, antioxidant enzymes concentration, lipid peroxidation, in vitro fertilizing potentials and conception rate. Current results indicated that addition of $0.05 \mathrm{mg} / \mathrm{ml} \mathrm{L}$ - carnitine to semen extender significantly $(\mathrm{P}<0.05)$ improved post-thawing motility, viability and acrosomal integrity $(63.33 \pm 9.28 \%, 133.33 \pm 9.40$ and $12.33 \pm 2.02 \%$, respectively) compared with control $(43.33 \pm 6.01 \%, 74.16 \pm 10.93$ and $24.67 \pm 2.03 \%$, respectively). Moreover, $0.05 \mathrm{mg} / \mathrm{ml}$ L- carnitine significantly increased $(\mathrm{P}<0.05)$ total antioxidant capacity $(\mathrm{TAC})$, superoxide dismutase (SOD) and glutathione peroxidase (GPx) concentrations $(0.50 \pm 0.07 \mathrm{m \mu} / \mathrm{ml}, 73.67 \pm 5.37 \mathrm{U} / \mathrm{ml}$ and $106.66 \pm 12.03 \mathrm{U} / \mathrm{L}$, respectively) with respect to the control $(0.19 \pm 0.01 \mathrm{~m} \mu / \mathrm{ml}, 27.33 \pm 3.49 \mathrm{U} / \mathrm{ml}$ and52.33 $\pm 4.09 \mathrm{U} / \mathrm{L}$, respectively). Furthermore, $0.05 \mathrm{mg} / \mathrm{ml} \mathrm{L-}$ carnitine significantly decreased $(\mathrm{P}<0.05)$ lipid peroxidation of the cryopreserved spermatozoa compared with the control semen $(11.00 \pm 1.73$ vs $24.82 \pm 4.90 \mathrm{nmol} / \mathrm{ml})$. Likewise, at this concentration sperm DNA damage, tail length and tail moment of the cryopreserved semen significantly $(\mathrm{P}<0.05)$ reduced $(1.87 \pm 0.36 \%, 1.83 \pm 0.33 \mu \mathrm{m}$ and 3.72 \pm 1.44 , respectively) compared with control $(3.47 \pm 0.13 \%, 3.48 \pm 0.17 \mu \mathrm{m}$ and $11.91 \pm 0.87$, respectively). Additionally, $0.05 \mathrm{mg} / \mathrm{ml}$ L- carnitine significantly $(\mathrm{P}<0.05)$ improved in vitro fertilization rate $(57.45 \%)$ and conception rate $(61.76 \%)$ compared with the control (33.33 and $37.93 \%$, respectively). In conclusion the use of $0.05 \mathrm{mg} / \mathrm{ml} \mathrm{L}$-carnitine in the freezing extender improves DNA integrity through enhancing the antioxidant defense of buffalo sperm cells and decreasing the rate of lipid peroxidation. Therefore, L-carnitine may improve sperm cryopreservation quality, reduce cryodamage and improve sperm fertilizing potential.
\end{abstract}

Key words: L- carnitine, cryopreservation, buffalo semen, DNA integrity, antioxidant activity

\section{INTRODUCTION}

Infertility and reduced fertility are one of the major problems in veterinary practices especially for valuable animals. Male infertility represented about $30 \%$ to $50 \%$ of infertility cases (Aliabadiet al., 2013).

Corresponding author: Dr. BADR, M.A.

E-mail address:magdybadr69@yahoo.com

Present address: Artificial Insemination and Embryo Transfer Department, Animal Reproduction Research Institute, Al Haram (P.O.B. 12556), Giza, Egypt
Semen cryopreservation is one of the most effective and acceptable methods to maintain male fertility potential. Long-term sperm storage, sperm banking and the possibility of storing the sperm of proven bull are the main objectives of using cryopreservation method. Unfortunately, despite many advantages of sperm cryopreservation, this methodentries some hazardous that reduces sperm fertilizing capacity through morphological damage, DNA damage and generally impaired sperm motility and viability (Singer et al., 1980). Several researchers found that cryopreservation decreases sperm motility parameters, normal morphology and increases 
programmed sperm death (Badr et al., 2010). Poly unsaturated fatty acids (PUFA) are a basic component of mammalian sperm cells, which contributing the major skeleton of its membrane structure, integrity, metabolism, and their ability to penetrate and fertilize the oocytes through many of physicochemical modifications (Guthrie and Welch, 2012). In this respect, it had been found that buffalo sperms were prone more to lipid peroxidation compared with bull sperm because it is rich in PUFA (Garg et al., 2009). Lipid peroxidation during in-vitro handling and sperm storage, are probably the primary causes of this fertility dysfunction (Cecil and Bakst, 1993).

It is extremely necessary to optimize cryopreservation method since it is an effective step in improving male infertility. Therefore, adding substances that prevent damage to sperm, to cryopreservation extender can improve sperm cryopreservation condition. These substances include antioxidants that are capable of preventing sperm damage and destruction through removing oxygen free radicals (Sarica et al., 2007).

L-carnitine (LC) is one of these antioxidants, which plays an important role in increasing vital capabilities of the sperm. Free LC is a high polarized and watersoluble substance being first isolated from bovine muscle in 1905, and its chemical structure was identified in 1948. LC is the only carnitine isomer, which is biologically active (Zare et al., 2009). LC is derived from lysine and methionine (amino acids) and is a foodstuff being found in meat and dairy products (Lenzi et al., 2004). Free LC is essential for betaoxidation (B-Oxidation) of long-chain fatty acids in mitochondrion. Fatty acids must be activated before entering the mitochondrion (making a connection with coenzyme A to form acetyl-CoA). Long-chain acetyl-CoA molecules cannot cross the inner mitochondrial membrane in the absence of LC. When fatty acids are entered the mitochondrion, betaoxidation and adenosine triphosphate formation (ATP) will begin (Peyvandi et al., 2009). ATP is an important fuel source for sperm motility (Stradaioli et al., 2004). Furthermore, LC through its antioxidant properties had been shown to increase the activity and levels of antioxidant enzymes such as superoxide dismutase and glutathione peroxidase (Sarica et al., 2007). Additionally, LC was to fulfill vital roles in sperm maturation and metabolism when passing through the epididymis (Yakushiji et al., 2006). The epididymis has the highest LC concentration found in body. LC concentration in epididymis is 2000 times higher than that in blood.

Therefore, we decided to investigate the effect of LCon morphology, the biochemical activities, sperm nuclear integrity and in vitro fertilizing potentials of the cryopreserved buffalo spermatozoain order to provide suitable strategies for improving the quality of cryopreservation, and preventing the risks of cryopreservation.

\section{MATERIALS AND METHODS}

\section{Diluent Preparation}

The cryoprotective extender used in the current study was composed of $2.42 \mathrm{~g}$ Tris, $1.48 \mathrm{~g}$ citric acid, 1.00 $\mathrm{g}$ fructose, $6.6 \mathrm{ml}$ glycerol, $20 \mathrm{~mL}$ egg yolk, $25 \mathrm{mg}$ gentamicin and 50,000 IU penicillin; all of these components were dissolved in $100 \mathrm{~mL}$ deionized water and supplemented with different concentrations of L- carnitine.

\section{Semen Collection}

Semen samples were obtained randomly from six evaluated buffalo bulls (aged 3 to $5 \mathrm{y}$ ) kept at the Animal Reproduction Research Institute farm (Cairo, Egypt). Two consecutive ejaculates were collected from each bull weekly for successive eight weeks using an artificial vagina. The ejaculates were pooled to eliminate variability between the evaluated samples. The semen samples were assessed for volume, sperm concentration and percentage of motile spermatozoa. The ejaculates with at least $70 \%$ motility, $800 \times 10^{6}$ sperm cells $/ \mathrm{ml}$ and $>85 \%$ normal sperm morphology were used for the present study. All experiments were done with at least 3 replicates for each group.

\section{Semen Processing}

After the evaluation of semen quality, the fresh semen samples were pooled and then split into 4 equal portions and diluted at $30^{\circ} \mathrm{C}$ with Tris-based extender supplemented with different concentrations of Lcarnitine $(0.01,0.05$ and $0.1 \mathrm{mg} / \mathrm{ml})$ Vs. Tris-based extender only (control) to obtain $120 \times 10^{6} \mathrm{sperm} / \mathrm{ml}$. The fresh semen samples were transferred to pre warmed tubes. Semen was cooled from 37 to $5^{\circ} \mathrm{C}$ throughout $60 \mathrm{~min}$ in a cold cabinet. The cooled semen was loaded into $0.25 \mathrm{ml}$ polyvinyl chloride straws (IMV, L'Aigle, France), horizontally placed in a refrigerator and kept at $4^{\circ} \mathrm{C}$ for $1 \mathrm{~h}$. These straws were then placed $6 \mathrm{~cm}$ above the liquid nitrogen surface where the temperature was approximately $-120^{\circ} \mathrm{C}$. After $15 \mathrm{~min}$, they were immersed directly into liquid nitrogen $\left(-196^{\circ} \mathrm{C}\right)$ for storage. The straws were stored at least for $24 \mathrm{~h}$ before evaluation (Badr et al., 2010). Frozen semen straws were thawed in water bath at $37^{\circ} \mathrm{C}$ for $30 \mathrm{sec}$. Post-thawing sperm motility; viability and acrosomal integrity were assessed.

\section{I- Assessing of sperm quality post-thawing I- a- Analysis of Sperm Motility}

The percentage of linear motile sperm was examined visually. For each treatment, 3 straws were thawed separately by immersion in a water bath at $37^{\circ} \mathrm{C}$ for $30 \mathrm{sec}$. The sperm samples were evaluated at $37^{\circ} \mathrm{C}$ by phase contrast microscope equipped with a warm stage at $200 \times$ magnifications. 


\section{I- b- Assess of Acrosomal Membrane Integrity}

Acrosomal integrity was assessed using silver nitrate stain in a procedure as described by Chinoy et al. (1992).

\section{I- c- Assess of plasma membrane integrity}

Plasma membrane integrity (PMI) of sperm was assessed using the hypo-osmotic swelling (HOS) test (Correa and Zavos, 1994). Fifty $\mu$ of each semen sample was mixed with $500 \mu \mathrm{l}$ of HOS solution and incubated at $37^{\circ} \mathrm{C}$ for $30 \mathrm{~min}$. After incubation, a $5 \mu \mathrm{l}$ semen sample drop was examined under a phasecontrast microscope $(400 \mathrm{x})$. A minimum of 100 sperm were counted for their swelling ability in HOS solution. The sperm characterized by coiling or swelling of the tail of varying degrees were considered to have an intact plasma membrane.

\section{II- Assessing of biochemical activity of the frozen semen: \\ II- a- Estimating Transaminases Enzymes}

Semen straws from each group were centrifuged at $800 \times \mathrm{g}$ for $10 \mathrm{~min}$ and supernatant was collected for estimating the Aspartate-Aminotransferase (AST); Alanine-Aminotransferase (ALT) and Alkaline Phosphatase (AKP) enzymes spectrophotometrically in all groups as described by Reitman and Frankel (1957).

\section{II-b-Estimating antioxidant activity:}

II-b-1-Total Antioxidant Capacity (TAC)

TAC of the frozen-thawed semen was estimated using a commercial kit (Antioxidant Capacity Assay Kit, Cayman Chemical Co. Ann Arbor, MI, USA) according to Cortassa et al. (2004). The reaction was measured spectrophotometrically at $532 \mathrm{~nm}$.

\section{II- b-2-Superoxide Dismutase (SOD)}

The SOD activity was measured according to Flohe and Otting (1984). Briefly, each semen sample was diluted 1:5 with phosphate buffer saline (PBS) $(\mathrm{pH}$ 7.0). The SOD activity was measured at $560 \mathrm{~nm}$ on a spectrophotometer and expressed as units per milliliter.

\section{II-b-3-Glutathione peroxidase (GPx)}

The GPx content of sperm was measured using the method of Sedlak and Lindsay (1968). The semen samples were precipitated with $50 \%$ trichloracetic acid $(\mathrm{vol} / \mathrm{vol})$ and then centrifuged at $1,000 \times \mathrm{g}$ at $22^{\circ} \mathrm{C}$ for $5 \mathrm{~min}$. The GPx activity was measured at $412 \mathrm{~nm}$ on a spectrophotometer. The values of GPx were expressed as units per liter.

\section{II-b-4-Lipid Peroxidation (LPO)}

The concentrations of malondialdehyde (MDA), as indices of the LPO in the sperm samples were estimated. An aliquot $(500 \mu \mathrm{l})$ of semen from each sample was centrifuged at $800 \times \mathrm{g}$ for $10 \mathrm{~min}$, sperm pellets were separated and washed by resuspending in
PBS and recentrifuging (three times). After the last centrifugation, $1 \mathrm{ml}$ of deionized water was added to spermatozoa and they were snap-frozen and stored at $-70^{\circ} \mathrm{C}$ till further analysis. The samples were thawed before the lipid peroxidation assay. The concentrations of Malondialdehyde (MDA), as indices of the LPO in the sperm samples, were measured using the thiobarbituric acid reaction according to the method of Placer et al. (1966). The MDA concentrations were expressed in $\mathrm{nmol} / \mathrm{ml}$.

\section{III-Assessment of Sperm DNA Integrity:}

DNA integrity and the incidence of DNA strand breaks or fragmentation were detected using the alkaline single cell gel electrophoresis (comet) assay according to Boe-Hansen (2005). Briefly, frozenthawed spermatozoa were diluted in PBS, embedded in agarose, followed by cell lysis, DNA decondensation, electrophoresis and DNA staining with $50 \mu \mathrm{L}$ of $20 \mu \mathrm{g} \mathrm{mL}-1$ ethidium bromide (Sigma, St. Louis, MO). The cells were then visualized by fluorescent microscopy. Intact nuclei in the comet assay appeared to have compact and brightly fluorescent heads; in contrast, strand breaks in damaged cells allow DNA migration during electrophoresis and a tail of DNA could be seen behind the head, giving the appearance of a comet (Hughes et al., 1996). After subjecting the spermatozoa to the comet assay, sperm nuclei were analyzed by computer software program (comet IV, 2001).

\section{IV- Evaluation of in vitro Fertilizing Potential:}

In vitro oocyte fertilization rate was examined on the base of the pronuclei number found in the oocyte after fertilization. In brief, the oocytes were matured in vitro according to Totey et al. (1992) and the nincubated with the capacitated sperm cells for $6 \mathrm{~h}$ at $5 \% \mathrm{CO}_{2}$ inhumid incubator according to Parrish et al. (1988). The ooocytes were fixed for $24 \sim 48 \mathrm{~h}$ in ethanol: acetic acid $(3: 1 \mathrm{v} / \mathrm{v})$, then stained with $1 \%$ Orcein dissolved in $45 \%$ aceticacid. The oocytes were evaluated under a phase-contrast microscope (Nikon, Tokyo, Japan). Oocytes were evaluated for normal fertilization according to Martino et al. (1994), on basis of oocyte that had set of male and female pronuclei in the ooplasm were considered to be fertilized normally.

\section{V- Evaluation of fertilizing potentials of treated semen (pregnancy rate).}

A preliminary fertility trial was performed to compare between control semen and the best Lcarnitine concentration treated spermatozoa. Buffalo cows were randomly assigned to two groups: group 1 (29 buffaloes) was inseminated using control semen; group (2) (34 buffaloes) was inseminated using $\quad 0.05 \mathrm{mg} / \mathrm{ml}$ L-carnitine treated semen. Pregnancy diagnosis was performed at 45 days postinsemination by rectal palpation. 


\section{Statistical Analysis:}

All data were analyzed by using Costat Computer Program (1986), Version 3.03 copyright Cottort Soft ware and were compared by the Least Significant Difference least (LSD) at 5\% levels of probability. The results were expressed as means \pm SE. The mean values of the percentages of motile sperm, acrosomeintactsperm, enzyme activity and embryo development were compared using Duncan's multiple range test by one way ANOVA procedure, when the F-value was significant $(\mathrm{P}<0.05)$. Sperm fertilizing capacity were assessed using Chi-square at $(\mathrm{P}<0.01$ and 0.05 , respectively).

\section{RESULTS}

The results presented in Table 1 revealed that, addition of L-carnitine to the freezing extender improved the freezability of buffalo bull spermatozoa compared with the control semen, in a dosedependent trend. Addition of $0.05 \mathrm{mg} / \mathrm{mlL}$-carnitine to semen extender, appeared to be the best concentration that increased significantly $(\mathrm{P}<0.05)$ the post-thawing sperm motility, viability index and maintained the plasma membrane and acrosomal integrity $(63.33 \pm 9.28 \%, 133.33 \pm 9.40,53.33 \pm 7.27 \%$ and $12.33 \pm 2.02 \%$, respectively) compared with the control semen $(43.33 \pm 6.01 \%, 74.16 \pm 10.93$, $31.66 \pm 3.33 \%$ and $24.67 \pm 2.03 \%$, respectively). However, high concentration of L-carnitine (0.1 $\mathrm{mg} / \mathrm{ml})$ significantly reduced $(\mathrm{P}<0.05)$ post-thawing sperm motility, viability index and increased the plasma membrane and acrosomal abnormalities $(41.66 \pm 6.01 \%, \quad 78.5 \pm 8.65, \quad 33.33 \pm 7.28 \%$ and $19.00 \pm 2.08 \%$, respectively).

Table (1): Effect of L-carnitine addition to freezing extender on post- thawed sperm characteristics.

\begin{tabular}{lcccc}
\hline Treatment & $\begin{array}{c}\text { Post-thawing motility } \\
(\boldsymbol{\%})\end{array}$ & Viability index & $\begin{array}{c}\text { HOST } \\
(\%)\end{array}$ & $\begin{array}{c}\text { Acrosomal integrity } \\
(\%)\end{array}$ \\
\hline Control & $43.33 \pm 6.01^{\mathrm{b}}$ & $74.16 \pm 10.93^{\mathrm{b}}$ & $31.66 \pm 3.33^{\mathrm{b}}$ & $24.67 \pm 2.03^{\mathrm{a}}$ \\
\hline $\mathrm{LC} 0.01 \mathrm{mg} / \mathrm{ml}$ & $48.33 \pm 4.40^{\mathrm{ab}}$ & $121.66 \pm 13.42^{\mathrm{a}}$ & $45.00 \pm 5.01^{\mathrm{ab}}$ & $15.33 \pm 2.27^{\mathrm{b}}$ \\
\hline $\mathrm{LC} 0.05 \mathrm{mg} / \mathrm{ml}$ & $63.33 \pm 9.28^{\mathrm{a}}$ & $133.33 \pm 9.40^{\mathrm{a}}$ & $53.33 \pm 7.27^{\mathrm{a}}$ & $12.33 \pm 2.02^{\mathrm{b}}$ \\
\hline $\mathrm{LC} 0.1 \mathrm{mg} / \mathrm{ml}$ & $41.66 \pm 6.01^{\mathrm{b}}$ & $78.5 \pm 8.65^{\mathrm{b}}$ & $33.33 \pm 7.28^{\mathrm{ab}}$ & $19.00 \pm 2.08^{\mathrm{ab}}$ \\
\hline
\end{tabular}

Three replications of the experiment were conducted. Results are presented as mean \pm SEM

Values with different superscripts in the same columns are significantly different at least $(\mathrm{P}<0.05)$.

- LC :L-carnitine HOST : hypoosmotic swelling test

Moreover, data presented in Table 2 showed the effect of L-carnitine supplementation to buffalo semen extender on its enzymatic activity. The current data clarified that, addition of $0.05 \mathrm{mg} / \mathrm{mL} \mathrm{L}$ carnitine to the semen extender maintained sperm cell membrane integrity and this appeared through reduction of AST, ALT and ALP enzymes leakage $(55.75 \pm 1.75, \quad 17.25 \pm 1.75$ and $16.13 \pm 1.65 \mathrm{U} / \mathrm{L}$, respectively) compared with the control extender $(100.25 \pm 7.73, \quad 26.5 \pm 2.10$ and $26.40 \pm 2.89 \mathrm{U} / \mathrm{L}$, respectively).

Table 2: Effect of different concentrations of L-carnitine on biochemical activity of buffalo spermatozoa.

\begin{tabular}{rlll}
\hline Treatment & $\begin{array}{c}\text { AST } \\
(\mathbf{U} / \mathbf{L})\end{array}$ & $\begin{array}{c}\text { ALT } \\
(\mathbf{U} / \mathbf{L})\end{array}$ & $\begin{array}{l}\text { ALP } \\
(\mathbf{U} / \mathbf{L})\end{array}$ \\
\hline Control & $100.25 \pm 7.73^{\mathrm{a}}$ & $26.5 \pm 2.10^{\mathrm{a}}$ & $26.40 \pm 2.89^{\mathrm{a}}$ \\
\hline $\mathrm{LC} 0.01 \mathrm{mg} / \mathrm{mL}$ & $65.00 \pm 8.92^{\mathrm{bc}}$ & $19.50 \pm 2.48^{\mathrm{b}}$ & $20.38 \pm 2.74^{\mathrm{b}}$ \\
\hline $\mathrm{LC} 0.05 \mathrm{mg} / \mathrm{mL}$ & $55.75 \pm 1.75^{\mathrm{c}}$ & $17.25 \pm 1.75^{\mathrm{b}}$ & $16.13 \pm 1.65^{\mathrm{b}}$ \\
\hline $\mathrm{LC} 0.1 \mathrm{mg} / \mathrm{mL}$ & $82.25 \pm 9.29^{\mathrm{ab}}$ & $21.50 \pm 1.34^{\mathrm{ab}}$ & $21.88 \pm 4.17^{\mathrm{ab}}$ \\
\hline
\end{tabular}

Three replications of the experiment were conducted. Results are presented as mean \pm SEM

Values with different superscripts in the same columns are significantly different at least $(\mathrm{P}<0.05)$.

AST: Aspartate-aminotransferase ALT: Alanine-aminotransferase ALP: Alkaline phosphatase 
Data regarding the effect of L-carnitine addition to the freezing extender on the total antioxidant capacity (TAC), antioxidant enzymes and lipid peroxidation of the cryopreserved semen are presented in Table 3 . In vitro provision of semen extender with $0.05 \mathrm{mg} / \mathrm{ml} \mathrm{L}$ carnitine significantly augmented $(\mathrm{P}<0.05)$ the total antioxidant, SOD and GPx concentrations $(0.50 \pm 0.07$ $\mathrm{m} \mu / \mathrm{ml}, \quad 73.67 \pm 5.37 \mathrm{U} / \mathrm{ml}$ and $106.66 \pm 12.03 \mathrm{U} / \mathrm{L}$, respectively) compared with the control extender $(0.19 \pm 0.01 \mathrm{m \mu} / \mathrm{ml}, 27.33 \pm 3.49 \mathrm{U} / \mathrm{ml}$ and $52.33 \pm 4.09$ $\mathrm{U} / \mathrm{L}$, respectively). Furthermore, data presented in Table 3 revealed that addition of $0.05 \mathrm{mg} / \mathrm{ml} \mathrm{L-}$ carnitine to the freezing extender significantly $(\mathrm{P}<0.05)$ diminished lipid peroxidation of the frozenthawed semen $(11.00 \pm 1.73 \mathrm{nmol} / \mathrm{ml})$ compared with the control extender $(24.82 \pm 4.90 \mathrm{nmol} / \mathrm{ml})$.

Table 3: Effect of L-carnitine addition to freezing extender on buffalo bull semen antioxidant activity.

\begin{tabular}{ccccc}
\hline Treatment & TAC & SOD & GPx & MDA \\
& $(\mathrm{m} \mu / \mathrm{mL})$ & $(\mathrm{U} / \mathrm{mL})$ & $(\mathrm{U} / \mathrm{L})$ & $(\mathrm{nmol} / \mathrm{ml})$ \\
\hline Control & $0.19 \pm 0.01^{\mathrm{b}}$ & $27.33 \pm 3.49^{\mathrm{c}}$ & $52.33 \pm 4.09^{\mathrm{a}}$ & $24.82 \pm 4.90^{\mathrm{a}}$ \\
\hline $\mathrm{LC} 0.01 \mathrm{mg} / \mathrm{mL}$ & $0.36 \pm 0.05^{\mathrm{a}}$ & $52.66 \pm 6.07^{\mathrm{b}}$ & $83.33 \pm 4.48 \mathrm{a}^{\mathrm{b}}$ & $17.35 \pm 0.94^{\mathrm{ab}}$ \\
\hline $\mathrm{LC} 0.05 \mathrm{mg} / \mathrm{mL}$ & $0.50 \pm 0.07^{\mathrm{a}}$ & $73.67 \pm 5.37^{\mathrm{a}}$ & $106.66 \pm 12.03^{\mathrm{a}}$ & $11.00 \pm 1.73^{\mathrm{b}}$ \\
\hline $\mathrm{LC} 0.1 \mathrm{mg} / \mathrm{mL}$ & $0.18 \pm 0.04^{\mathrm{b}}$ & $31.00 \pm 5.51^{\mathrm{c}}$ & $59.67 \pm 10.67^{\mathrm{bc}}$ & $20.75 \pm 2.92^{\mathrm{a}}$ \\
\hline
\end{tabular}

Three replications of the experiment were conducted. Results are presented as mean \pm SEM

Values with different superscript in the same column are significantly different $(p<0.05)$.

LC: L-carnitine; TAC: Total Antioxidant Capacity; SOD: Superoxide Dismutase; GPx: glutathione peroxidase; MDA:Malondialdyhide

With respect to the effect of L-carnitine addition to the freezing extender on the DNA integrity of the frozen buffalo spermatozoa are demonstrated in Table 4 and Fig (1). The present data indicated that, in vitro provision of semen extender with $0.05 \mathrm{mg} / \mathrm{ml}$ L-carnitine significantly decreased $(\mathrm{P}<0.05)$ the DNA fragmentation, tail length and tail moment of the frozen-thawed buffalo semen $(1.87 \pm 0.36 \%$, $1.83 \pm 0.33 \mu \mathrm{m}$ and $3.72 \pm 1.44$, respectively) as compared with the control extender $(3.47 \pm 0.13 \%$, $3.48 \pm 0.17 \mu \mathrm{m}$ and $11.91 \pm 0.87$, respectively).

Table 4: Effect of different concentrations of L-carnitine on DNA integrity of the cryopreserved buffalo spermatozoa.

\begin{tabular}{llll}
\hline Treatment & DNA integrity $(\%)$ & Tail length $(\mu \mathrm{m})$ & $*$ Tail moment \\
\hline Control & $3.47 \pm 0.13^{\mathrm{a}}$ & $3.48 \pm 0.17^{\mathrm{a}}$ & $11.91 \pm 0.87^{\mathrm{a}}$ \\
\hline LC $0.01 \mathrm{mg} / \mathrm{ml}$ & $2.75 \pm 0.06^{\mathrm{b}}$ & $2.71 \pm 0.03^{\mathrm{b}}$ & $7.46 \pm 0.24^{\mathrm{b}}$ \\
\hline LC $0.05 \mathrm{mg} / \mathrm{ml}$ & $1.87 \pm 0.36^{\mathrm{c}}$ & $1.83 \pm 0.33^{\mathrm{c}}$ & $3.72 \pm 1.44^{\mathrm{c}}$ \\
\hline LC $0.1 \mathrm{mg} / \mathrm{ml}$ & $3.05 \pm 0.10^{\mathrm{ab}}$ & $2.98 \pm 0.11^{\mathrm{a}}$ & $9.12 \pm 0.65^{\mathrm{ab}}$ \\
\hline
\end{tabular}

Three replications of the experiment were conducted. Results are presented as mean \pm SEM

Values with different superscripts in the same column are significantly different $(\mathrm{p}<0.05)$.

*tail moment is the result of multiplying the percent of DNA fragmentation by Tail length. 

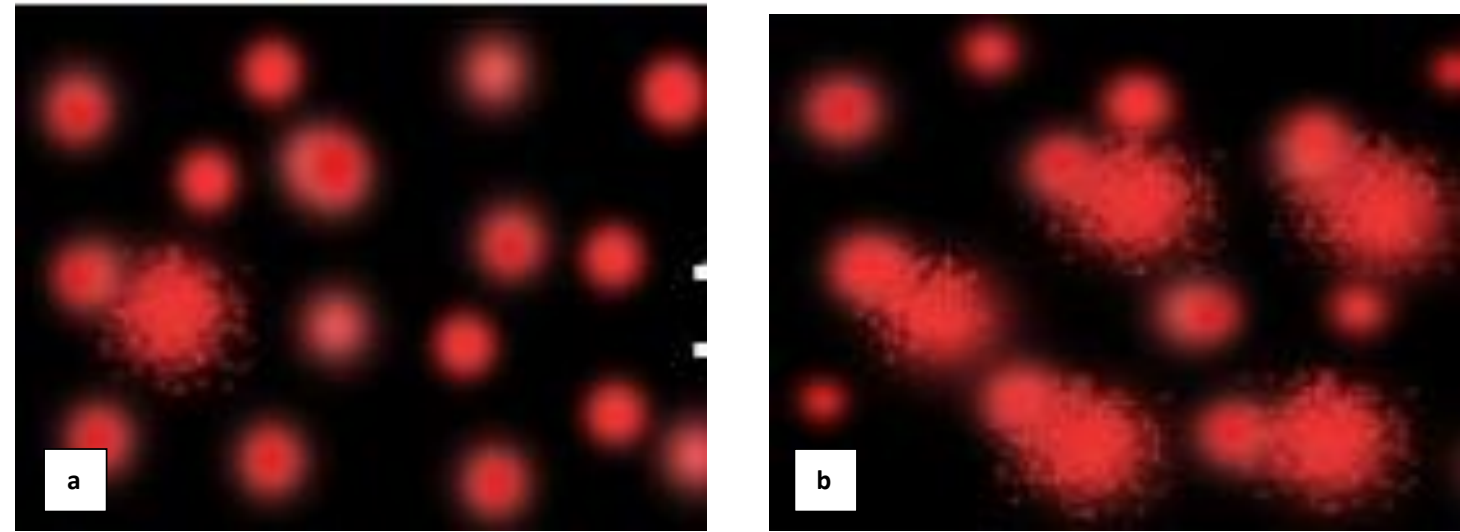

Fig. 1 (a): The single cell gel electrophoresis (comet) assay showed reduction in the DNA fragmentation as represented by a limited amount of DNA present in the comet tail of buffalo spermatozoa cryopreserved in freezing extender suplemented with 0.05 l- carnitine. (b): The single cell gel electrophoresis (comet) assay showed increased in the DNA fragmentation of the buffalo spermatozoa cryopreserved in control extender.

Data concerning the effect of replenishing of semen extender with L-carnitine on the in vitro fertilizing potentials of buffalo oocytes are presented in Table 5 . The current results revealed that, addition of 0.05 $\mathrm{mg} / \mathrm{ml} \mathrm{L}$-carnitine to the freezing extender resulted in a significant increase $(\mathrm{P}<0.05)$ in the in vitro fertilization rate $(57.45 \%)$ compared with the control treated group $(33.33 \%$, respectively).

Table (5): Effect of L-carnitine supplementation to buffalo semen diluent on the in vitro fertilizing capacity

\begin{tabular}{|c|c|c|c|}
\hline Treatment & No. oocytes & Penetration rate $(\%)$ & Fertilization rate $(\%)$ \\
\hline Control & 39 & $27(69.23)^{\mathrm{a}}$ & $13(33.33)^{\mathrm{a}}$ \\
\hline $\mathrm{LC} \quad 0.01 \mathrm{mg} / \mathrm{ml}$ & 42 & $29(69.05)^{\mathrm{a}}$ & $19(45.24)^{\mathrm{ab}}$ \\
\hline LC $0.05 \mathrm{mg} / \mathrm{ml}$ & 47 & $33(70.21)^{\mathrm{a}}$ & $27 \quad(57.45)^{\mathrm{b}}$ \\
\hline $\mathrm{LC} 0.1 \mathrm{mg} / \mathrm{ml}$ & 43 & $30(64.76)^{\mathrm{a}}$ & $17 \quad(39.53)^{\mathrm{a}}$ \\
\hline
\end{tabular}

Five replications of the experiment were conducted. Percentages are based on the number of oocytes examined. Values with different superscripts in the same column are significantly different $(P<0.05)$.

$\mathrm{LC}:$ L-carnitine

Table (6) demonstrated that there was significant increase in $(\mathrm{P}<0.05)$ in the conception rate of buffalo cows inseminated with frozen semen treated with $0.05 \mathrm{mg} / \mathrm{ml}$ ofL-carnitine $(61.76 \%)$ compared with the control group $(37.93 \%)$. Furthermore the conception rate after first insemination was high increased $(\mathrm{P}<0.01)$ in the $0.05 \mathrm{mg} / \mathrm{ml}$ L-carnitine treated semen $(47.06 \%)$ compared with the control semen (13.79\%).

Table (6): Effect of L-carnitine addition to buffalo semen diluent on the pregnancy rate

\begin{tabular}{|c|c|c|c|c|c|}
\hline Treatment & $\begin{array}{c}\text { No. of Inseminated } \\
\text { buffaloes }\end{array}$ & $\begin{array}{l}\text { First insemination/ } \\
\text { conception }(\%)\end{array}$ & $\begin{array}{c}\text { Second } \\
\text { insemination } \\
\text { /conception }(\%)\end{array}$ & \multicolumn{2}{|c|}{ Pregnancy rate $(\%)$} \\
\hline Control & 29 & $4(13.79)^{\mathrm{a}}$ & $7(24.14)^{\mathrm{a}}$ & 11 & $(37.93)^{\mathrm{a}}$ \\
\hline LC $0.05 \mathrm{mg} / \mathrm{ml}$ & 34 & $16(47.06)^{b}$ & $5(14.71)^{b}$ & 21 & $(61.77)^{\mathrm{b}}$ \\
\hline
\end{tabular}

Values with different superscripts in the same column are significantly different $(P<0.05)$.

L.C means L-carnitine 


\section{DISCUSSION}

L-carnitine is a well-known cellular antioxidant, but there is a paucity of exploration about its protective role during buffalo semen cryopreservation. The present study revealed that addition of $0.05 \mathrm{mg} / \mathrm{ml} \mathrm{L-}$ canrnitine to the semen extender enhanced postthawing motility, viability of the cryopreserved spermatozoa and significantly reduced acrosomal deterioration. These results are in agreement with Lenzi et al. (2003) and Agarwal and Said (2004) who reported that L-carnitine can improve sperm motility and viability.

The beneficial effect of L-carnitine on buffalo sperm cell quality might be attributing to its critical role in improving the energy metabolism. The current results indicated that L-carnitine resulted in a significant increase in ATP concentration. This result coincided with the interpretation that mentioned byKeskin et al. (2015) who reported that L-carnitine is a natural nutrient related to $\mathrm{B}$ vitamins that is essential for $\beta$ oxidation of fatty acids in mitochondria to generate adenosine triphosphate via mitochondrial $\beta$-oxidation and subsequent oxidative phosphorylation (Perchec et al., 1995, Parikh et al., 2009 and Flanagan et al., 2010). Furthermore, Liu et al. (2002) reported that Lcarnitine acted by stabilizing the mitochondrial membrane, protecting the cell from apoptosis and markedly enhanced mitochondrial functions and its general metabolic activity by reducing oxidative stress pathways.

Moreover L-carnitine appears to have other functions which go beyond improving the energy metabolism. The beneficial effects of L- carnitine appear to arise, at least partially, from its antioxidant properties, which include the upregulation of the level and the elevation of the activities of antioxidant enzymes that may protect sperm membranes against toxic reactive oxygen species. Under physiological conditions, spermatozoa produce small amounts of ROS, which are needed for capacitation and acrosomal reaction (Agarwal et al., 2003).Since buffalo spermatozoa contain large amounts of polyunsaturated fatty acids, it is extremely sensitive to lipid peroxidation (Agarwal and Prabakaran 2005). Normally, antioxidants such as superoxide dismutase, glutathione peroxidase, glucose-6- phosphate dehydrogenase enzymes prevent damage to sperm membrane through super oxide and hydrogen peroxide anions breakdown.

In the current study, L-carnitine supplementation to tris extender significantly increased TAC, GPx and SOD levels and reduced MDA concentration in $0.05 \mathrm{mg} / \mathrm{mlL}$-carnitine treated group compared with the control group, suggesting that L-carnitine has an antioxidant effect. These increased levels of antioxidants lead to reduced levels of free radicals available for lipid peroxidation, which protect the spermatozoon membranes resulting in an increase in sperm cell viability. These results are in accordance with Steinberg (1995) and Sayed-Ahmed et al. (2001) who reported that L-carnitine prevented the increase in MDA and the decrease in GSH. Dayanandan et al. (2001) noted elevation in GSH and GPx levels with carnitine supplementation in rats. Moreover, Rajasekaret al. (2005) found significantly increases antioxidant enzyme levels (GSH, SOD, CAT and GPx) of rats treated with L-carnitine compared with untreated rats. In the present study, increase antioxidant enzymes with L-carnitine treatment may be due to enhancement of transport of fatty acids by carnitine into mitochondria for energy production (Dayanandan et al., 2001). In addition to its energy production and antioxidant effects, it has reported that carnitine inhibits the microsomal peroxidation and it has a role in chelating free $\mathrm{Fe}_{2}+$ ions and by this way it reduces free radical generation and improves the overall level and activity of antioxidant enzymes in the cell (Sushama Kumari et al., 1989). Moreover, Pignatelli et al. (2003) and Vicari and Calogero (2001) demonstrated that L-carnitine can reduces oxidative stress via interfering with arachidonic acid incorporation into phospholipids and protein kinase $C$ mediated NADPH oxidase system as well as potentiate the repairing mechanism.

The current study clarified that L- carnitine has fantastic protecting functions on the DNA integrity of buffalo spermatozoa in a dose dependent trend. The current results indicated that addition of $0.05 \mathrm{mg} / \mathrm{ml}$ L-carnitine to sperm freeze extender significantly decreased the rate of DNA damage. These results are in consistent with Abdelrazik et al. (2009) who found that; L-carnitine protects the sperm DNA and prevents protein oxidation and lactate oxidative damage. This result may be attributed to the antioxidant effect of 1 - carnitine, where, oxidative damage can cause base degradation, DNA fragmentation and cross-linking of proteins (Arabi, 2004 and Sharma et al., 2004). In molecular structure of DNA, free radicals can lead to the oxidation of purine and pyrimidine bases, breakage in one or two chromosome strands, formation of positions lacking base, formation of cross-bridges between DNA and protein, and change in deoxyribose sugar. Free radicals can oxidatively attack critical bio-molecules such as DNA and change DNA structure causing infertility (Rehman et al., 2000). Guanine (G) is the most common organic base attacked oxidatively by free radicals and is converted to 8-hydroxyguanin (8OHG) (Hammadeh et al., 2001).Adding L-carnitine to sperm freeze extender can lead to the protection of DNA and cell membrane against damages caused by oxygen free radicals (Blokhina et al., 2003).

The improvementin the in vitro fertilization and conception ratesrecorded in the $0.05 \mathrm{mg} / \mathrm{ml} \mathrm{L}$ carnitine treated semen might be emphasized by 
increased ATP production and antioxidant effect of 1carnitine. These results are consistent with Rizzo et al. (2010) and Manzano et al. (2015) who reported that LC have a beneficial roles on mammalian embryos metabolism and development; through its contribution in lipid and energy metabolism, as well as its antioxidant effects by enhancing the activity of numerous antioxidant enzymes in addition to its antiapoptotic effect.

However, the current study demonstrated that high LC concentration $0.1 \mathrm{mg} / \mathrm{ml} \mathrm{LC}$ resulted in a drastic effect on semen function and fertilizing potential. This may be due to the cryopreserved spermatozoa at this concentration become more susceptible to the cryotoxic effect of $\mathrm{H}_{2} \mathrm{O}_{2}$ or due to the removal of all oxygen free radicals which is an important mediatorof sperm function (Agarwaland Prabakaran, 2005).

In conclusion the use of $0.05 \mathrm{mg} / \mathrm{ml} \mathrm{L}$-carnitine in the freezing extender improves DNA integrity through enhancing the antioxidant defense of buffalo sperm cells and decreasing the rate of lipid peroxidation. Therefore, L-carnitine may improve sperm cryopreservation quality, reduce cryodamage and improve sperm fertilizing potential.

\section{REFERENCES}

Abdelrazik, H.; Sharma, R.; Mahfouz, R. and Agarwal, A. (2009): L-carnitine decreases DNA damage and improves the in vitro blastocyst development rate in mouse embryos. Fertil Steril; 91: 589-596.

Agarwal, A. and Prabakaran, S.A. (2005): Oxidative stress and antioxidants in male infertility: a difficult balance. Iranian J. Reprod Med.; 3 (1): $1-8$.

Agarwal, A. and Said, T.M. (2004): Carnitines and male infertility. Reprod Biomed Online; 8: 376-384.

Agarwal, A.; Saleh, R.A. and Bedaiwy, M.A. (2003): Role of reactive oxygen species in the pathophysiology of human reproduction. Fertil Steril; 79: 829-843.

Aliabadi, E.; Karimi, F.; Rasti, M.; Akmali, M. and Esmaeilpour, T. (2013): Effects of L-carnitine and Pentoxifylline on the Activity of Lactate Dehydrogenase C4 isozyme and Motility of Testicular Spermatozoa in Mice. J. ReprodInfertil; 14(2):56-61.

Arabi, M. (2004): Nicotinic infertility: assessing DNA and plasma membrane integrity of human spermatozoa. J. andrologia; 36: 305310 .

Badr, M.R.; Mary G. Abd El- Malak and Hassan, H.M. (2010): Effect of trehalose on cryopreservation, oxidative stress and DNA integrity of buffalo spermatozoa. J. Reproduction and infertility, 1 (2): 50-57.
Blokhina, O.; Virolainen, E. and Fagerstedt, K.V. (2003): Antioxidants, Oxidative Damage and Oxygen Deprivation Stress a Review. Annals Botany, 91: 179-194.

Boe-Hansen, G.B. (2005): Hydrogen peroxide alters the physical state and function of the plasma membrane of pulmonary artery endothelial cells. J. Cell Phys., 20: 362-374.

Cecil, H.C. and Bakst, M.R. (1993): In vitro peroxidation of turkey spermatozoa. Poult Sci; 72:1370-1378.

Chinoy, N.J.; Ranga, G.M.; Highland, H.N.; D'Souza, K.J. and Sequeira, E. (1992): A modified method for the differential staining of spermatozoa using alcoholic acidic silver nitrate. Int. J. Fertil; 37: 232-236.

Correa, J.R. and Zavos, P.M. (1994): The hypoosmotic swelling test: its employment as an assay to evaluate the functional integrity of the frozen-thawed bovine sperm membrane. Theriogenology, 42: 351-360.

Cortassa, S.; Aon, M.A.; Winslow, R.L. and O'Rourke, B. (2004): A mitochondrial oscillator dependent on reactive oxygen species. Biophysic. J., 87: 2060-2073.DOI: 10.1529/biophysj.104.041749

Dayanandan, A.; Kumar, P. and Panneerselvam, $C$. (2001): Protective role of L-carnitine on liver and heart lipid peroxidation in atherosclerotic rats. Journal of Nutritional Biochemistry, 12: 254-257.

Flanagan, J.L.; Simmons, P.A.; Vehige, J.; Willcox, M.D.P. and Garrett, Q. (2010): Role of carnitine in disease. Nutrition and Metabolism, 7: 1-14.

Flohe, L. and Otting, F. (1984): Superoxide dismutase assays. Methods Enzymol., 105: 93104.

Garg, A.; Kumaresan, A. and Ansari, M.R. (2009): Effects of hydrogen peroxide $\left(\mathrm{H}_{2} \mathrm{O}_{2}\right)$ on fresh and cryopreserved buffalo sperm functions during incubation at 37 degrees $\mathrm{C}$ in vitro. Reprod in Domest Anim; 44(6): 907-912.

Guthrie, H.D. and Welch, G.R. (2012): Effects of reactive oxygen species on sperm function. Theriogenology,78: 1700-1708.

Hammadeh, M.E.; Greiner, S.; Rosenbaum, P. and Schmidt, W. (2001): Comparison between human sperm preservation medium and TESTYolk buffer on protecting chromatin and morphology integrity of human spermatozoa fertile and subfertile men after freeze-thawing procedure, Germany, J. Andrology, 22: 6.

Hughes, C.M.; Lewis, S.E.M.; McKelvey-Martin, V.J. and Thompson, W. (1996): Aomparison of baseline and induced DNA damage in human spermatozoa from fertile and infertile men, using a modified comet assay. Mol. Hum. Reprod., 2: 613-619. 
Keskin, E.; Uluisik, D.; and Altin, M. (2015): Antioxidant Effect of L-carnitine in Rats Fed Cholesterol Rich Diet. Animal and Veterinary Sciences, 3(4): 113-116.

Lenzi, A.; Lombardo, F.; Sgro, P.; Salacone, P.; Caponecchia, L.; Dondero, F. and Gandini, L. (2003): Use of carnitine therapy in selected cases of male factor infertility: a double-blind crossover trial. Fertil Steril; 79: 292-300.

Lenzi, A.; Sgro, P.; Salacine, P.; Paoli, D.; Gilio, B. and Lombardo, F. (2004): A placebocontrolled double-blind randomized trial of the use combind L-carnitine and L-acetyLcarnitine treatment in men with asthenozoospermia, Fertil Steril, 81(6).

Liu, J.; Head, E.; Gharib, A.M.; Yuan, W.; Ingersoll, R.T.; Hagen, T.M.; Cotman, C.W. and Ames, B.N. (2002): Memory loss in old rats is associated with brain mitochondrial decay and RNA/DNA oxidation: Partial reversal by feeding acetyl-L-carnitine and/or R-alpha lipoic acid. Proc Natl Acad Sci; 19, 99 (4): 2356-2361.

Manzano, P.C.V.J.; Ocampo, M.B.; Ocampo, L.C.; Maylem, E.R.S. and Lazaro, J.V. (2015): Improved Bovine Blastocyst Developmental Potential by L-carnitine Supplementation. IJSK, 3(1): 021-029.

Martino, A.; Mogas T.; Palomo, M.J. and Paramio, M.T. (1994): Meiotic competence of prepubertal goat oocytes. Theriogenology, 41: 969-980.

Parikh, S.; Saneto, R.; Falk, M.J.; Anselm, I.; Cohen, B.H. and Haas, R. (2009): A Modern Approach to the Treatment of Mitochondrial Disease. Current Treatment Options in Neurology; 11, 414-430.

Parrish, J.J.; Susko-Parrish, J.; Winer, M.A. and First, N.L. (1988): Capacitation of bovine sperm by heparin. Biol. Reprod; 38:11711180.

Perchec, G.; Jeulin, C.; Cosson, J.; André, F. and Billard, R. (1995): Relationship between sperm ATP content and motility of carp spermatozoa. J. Cell Sci; 108 (2): 747-753.

Peyvandi, S.; Karimpour, A. and Moslemizadeh, N. (2009): Investigation of the effect of Lcarnitine on improving the parameters of infertile men's sperm, a cross-sectional clinical trial, Tehran: Fertility and Infertility Journal, 10(4): 245-251.

Pignatelli, P.; Lenti, L.; Sanguigni, V.; Frati, G.; Simeoni, I.; Gazzaniga, P.P.; Pulcinelli, F.M. and Violi, F. (2003): Carnitine inhibits arachidonic acid turnover, platelet function, and oxidative stress. Am. J. Physiol Heart Circ Physiol; 284 (1): 41-48.

Placer, Z.A.; Cushman, L.L. and Johnson, B.C. (1966): Estimation of product of lipid peroxidation (malonyldialdehyde) in biochemical systems. Anal. Biochem., 16: 359-364.

Rajasekar, P.; Ravichandran, M.K. and Anuradha, C.V. (2005): Intraperitoneal L-carnitine regulates lipid metabolism and reduces oxidative stress in fructose-induced hyperlipidemic rats. Diabetologia Croatica, 34(3): 87-95.

Rehman, A.; Jenner, A. and Halliwell, B. (2000): Gas chromatography - mass spectrometry analisisaf DNA: optimization of protocols for isolation andanalysis of DNA from human blood, Methods in Enzymal, 319: 401-417.

Reitman, S. and Frankel, S. (1957): A Colorimetric method for the determination of serum glutamic oxaloacetic trans-aminase and serum glutamic pyruvic transminase. Am. J. Clini. Pathol., 28: 56-63.

Rizzo, A.M.; Berselli, P.; Zava, S.; Montorfano, G.; Negroni, M. and Corsetto, P. (2010): Endogenous antioxidants and radical scavenger. Adv Exp Med Bio; 698:52-67.

Sarica, S.; Corduk, M.; Suicmez, M.; Cedden, F.; Yildirim, M. and Kilinc, K. (2007): The effects of dietary L-carnitine supplementation on semen traits, reproductive parameters, and testicular histology of Japanese quail breeders. J. Appl Poult Res; 16:178-186.

Sayed-Ahmed, M.M.; Khattab, M.M.; Gad, M.Z. and Mostafa, N. (2001): L-carnitine prevents the progression of atherosclerotic lesions in hypercholesterolaemic rabbits. Pharmacological Research, 44(3): 235-242.

Sedlak, J. and Lindsay, R.H.C. (1968): Estimation of total, protein-bound and nonprotein sulfhydryl groups in tissue with Ellman's reagent. Anal. Biochem., 25:192-205.

Sharma, R.K.; Said, T. and Agarwal, A. (2004): Sperm DNA damage and its clinical relevance in assessing reproductive outcome. Asian $\mathrm{J}$. Androl; 6: 139-148.

Singer, R.; Sagiv, M.; Landau, B.; Allalouf, D.; Segenreich, E. and Servadio, C. (1980): Motility and vitality of human spermatozoa at various time intervals after ejaculation. Experientia; 36:578-579.

Steinberg, D. (1995): Role of oxidized LDL and antioxidants in atherosclerosis. Advances Experimental Medicine and Biology, 369: 3948.

Stradaioli, G.; Sylla, L.; Zelli, R.; Chiodi, P. and Monaci, M. (2004): Effect of Lcarnitine administration on the seminal characteristics of oligoasthenospermic stallions. Theriogenology, 62: 761-777.

SushamaKumari, S.; Jayadeep, A.; Kumar, J.S. and Menon, V.P. (1989): Effect of carnitine on malondyaldehyde, taurine and glutathione levels in the heart of rats subjected to myocardial stress by isoproteinol. Indian 
Journal of Experimental Biology, 27(2): 134137.

Totey, S.M.; Singh, G.; Taneja, M.; Pawshe, C.H. and Talwar, G.P. (1992): In vitro maturation, fertilization and development of follicular oocytes from buffalo (Bubals bubalis). J. Reprod Ferti; 95: 597-607.

Vicari, E. and Calogero, A.E. (2001): Effects of treatment with carnitines in infertile patients with prostate-vesiculo-epididymitis. Hum Reprod; 16:2338-2342.
Yakushiji, K.; Kai, S.; Yamauchi, M.; Kuwajima, M.; Osada, Y. and Toshimori, K. (2006): Expression and distribution of OCTN2 in mouse epididymis and its association with obstructive azoospermia in juvenile visceral steatosis mice. Int. J. Urol; 13: 420-426.

Zare, Z.; Imani, H.; Mohammadi, M.; Mofid, M. and Dashtnavard, H. (2009): Effect of oral Lcarnitine on testicular tissue, sperm parameters and daily production of sperm in adult mouse, Sabzevar: Yakhteh (cell) Medical Journa, 11(4): 382-389.

\section{دراسة تأثير لـ كارنتين علي قدرة حيامن الجاموس للتجميد ، انزيمات الاكسدة والتغيرات في تركيب المحتوي النووي التوني}

مجي ربضان بلر ، ابتهال (بر/هيم ، رجب عبل المنعم دحريج ، معدوح حسين ، هاني محد حسن

Email: magdybadr69@yahoo.com

Assiut University web-site: $\underline{w w w . a u n . e d u . e g}$

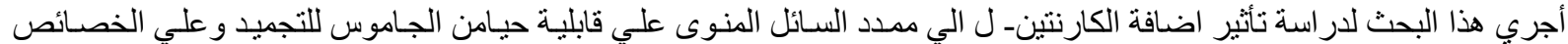

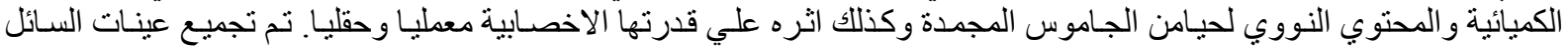

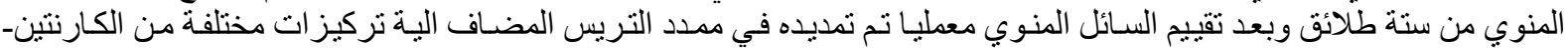

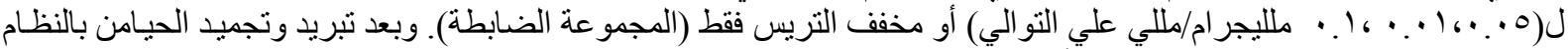

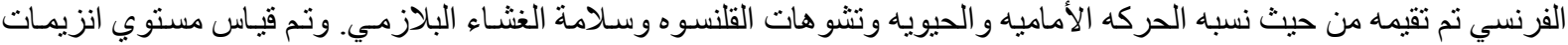

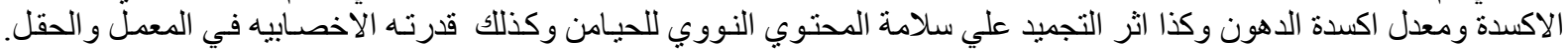

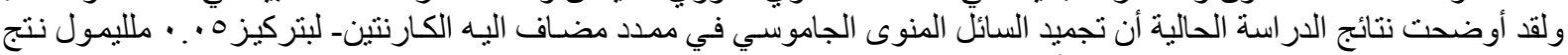

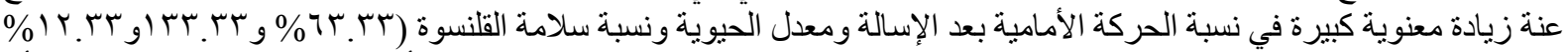

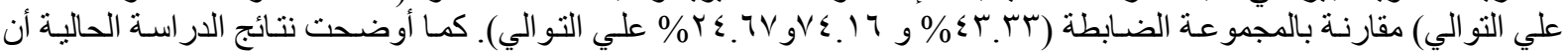

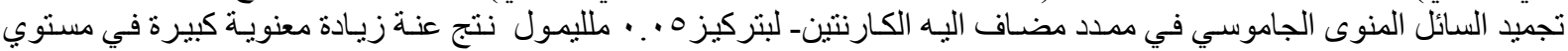

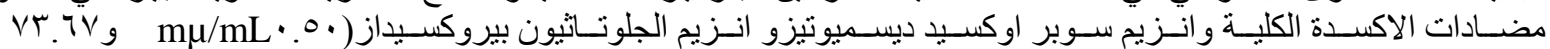

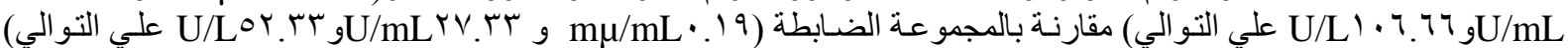

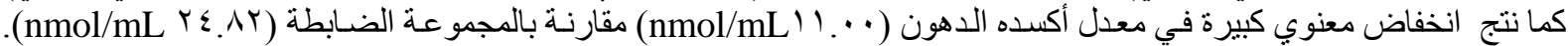

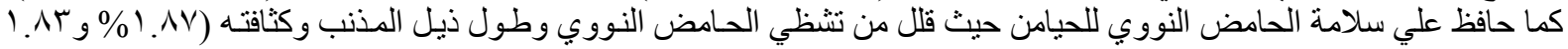

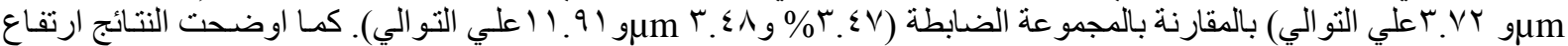

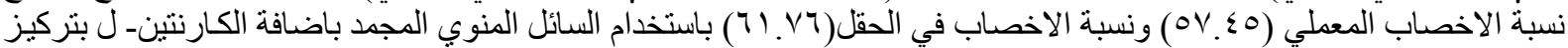

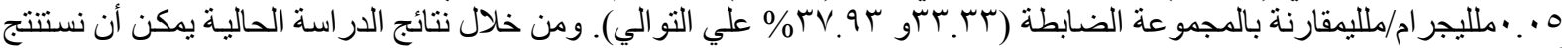

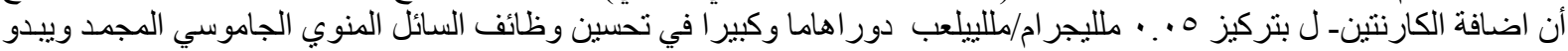

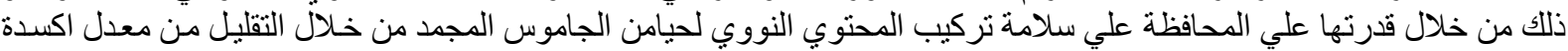
الدهون وارتفاع تزكيز انزيمات الاكسدة. 